\title{
Effects of Intra-Row Spacing of Sesame (Sesamum indicum L.) and Frequency of Weeding on Yields of Maize- Sesame Intercrop in Makurdi, Nigeria
}

\author{
M. O. Ijoyah ${ }^{1 *}$, J. A. Idoko ${ }^{1}$, T. Iorlamen ${ }^{1}$ \\ ${ }^{1}$ Department of Crop Production, University of Agriculture, P.M.B. 2373, Makurdi, Nigeria \\ *E-mail address: mikejoy2005@yahoo.com.
}

Keywords: intercropping; intra-row spacing; weeding frequency; maize; sesame

\begin{abstract}
Field experiments were conducted from July to October, during 2012 and 2013 cropping seasons, at the Research Farm, University of Agriculture, Makurdi, Nigeria, to evaluate the effects of intra-row spacing of sesame and frequency of weeding on yields of maize-sesame intercrop. The trial was a $3 \times 3$ factorial experiment fitted in a randomized complete block design with four replications. Nine of the treatments consisted of intercropped maize with sesame sown at the intra-row spacing of $10 \mathrm{~cm}, 15 \mathrm{~cm}$ and $20 \mathrm{~cm}$, and at the varied weeding frequencies: maizesesame intercrop sown on plots weeded once $(1 \mathrm{x})$ at 3 weeks after planting (WAP); maize-sesame intercrop sown on plots weeded twice $(2 \mathrm{x})$ at 3 and 6 WAP; maize-sesame intercrop sown on plots not weeded $(\mathrm{NW})$. Sole sesame and sole maize respectively sown at their recommended intra-row spacing of $10 \mathrm{~cm}$ and $30 \mathrm{~cm}$ and at their recommended frequency of weeding ( $2 \mathrm{x}$ at 3 and $6 \mathrm{WAP}$ ) constituted the tenth and eleventh treatments, which also served as control plots. The results obtained showed that in a maize-sesame intercrop, increasing intra-row spacing of sesame up to 20 $\mathrm{cm}$, on plots weeded $2 \mathrm{x}$ at 3 and $6 \mathrm{WAP}$, significantly $(\mathrm{P} \leq 0.05)$ produced the highest intercrop yields of maize and sesame. This level of treatment not only recorded the lowest competitive pressure, but gave the highest total intercrop yields, highest land equivalent coefficient values (1.01 and 1.13 respectively, in years 2012 and 2013), indicating the highest yield advantage, and highest land equivalent ratio (LER) values of 2.11 and 2.25 respectively recorded for years 2012 and 2013 . With these LER values, $52.6 \%$ and $55.6 \%$ of land were respectively saved in years 2012 and 2013, which could be used for other agricultural purposes. The implication of study showed that, to maximize intercrop yields of maize and sesame in a maize-sesame intercrop, the appropriate intrarow spacing for sesame is $20 \mathrm{~cm}$, while the optimal frequency of weeding is $2 \mathrm{x}$ at 3 and 6 WAP. This should therefore, be recommended for Makurdi location, Nigeria.
\end{abstract}

\section{INTRODUCTION}

Sesame (Sesamum indicum L.) is an annual crop and one of the important oil crops of the world (Dudley et al., 2000). The world hectarage exceeds 6 million tonnes and world output stood at 2.4 million tonnes (Kafiriti and Deckers, 2001). In Africa, Nigeria is the second largest producer after Sudan (Chiezey, 2001). Sesame oil is of good quality (Alam et al., 2007). According to Kamara et al., (2007), the oil is used for cooking, baking, candy making, soaps, lubricant, hair treatment, industrial uses and alternative medicine (in the control of blood pressure, stress and tension). Leaves are used in vegetable soup, seeds are consumed when fried and mixed with sugar in most African countries, while stems are used in making paper, fuel wood and source of potash after burning (Alam et al., 2007).

Among the cereals, maize (Zea mays L.) ranked third following wheat and rice in the world production (Kamara et al., 2005). In Nigeria, based on the area cropped and quantity produced, maize was the country's third most important cereal crop following sorghum and millet (Uzozie, 2001). It is used mainly for human food and livestock feed. In the industry, it is important in the production of starch, oil and alcohol (Kling and Edmeades, 1997).

Weeds have been defined as higher plants in the agro-ecosystem, which are not sown, undesirable, out of place or generally as plants which do more harm than good (Bedry, 2007). Weeds have been a problem to man ever since he began cultivating crops about 10,000 BC (Silva et 
al., 2004). Its removal is useful because the unwanted plant compete with crops for water, soil nutrients, light and space, thus reducing crop yields (El Naim and Ahmed, 2010). Joshi (2004) noted that weeds can deprive the crop of 30-50\% of applied nutrients and $20-40 \%$ of the soil moisture. Hoe weeding is by far the most widely practiced cultural weed control method by farmers in the country, probably because of the productive cost of herbicides, fear of toxic residue coupled with the lack of knowledge on their use (Mubarak, 2004), but when done timely, have controlled weeds effectively, thereby improving crop yields (Iremiren, 1988). Maize and sesame cannot compete effectively with weeds, particularly 3 to 6 weeks after planting (WAP), therefore the early removal of weeds is important (Silva et al., 2004; Olabode et al., 2010).

Poggio (2005) reported that under intercropping, good husbandry practices such as use of fertilizers, good seed varieties, appropriate plant populations, optimal frequency of weeding, insect and disease control measures are important in increasing yields of component crops. A number of studies have been conducted on sole maize and sole sesame as affected by intra-row spacing and frequency of weeding (Jagtap et al., 1988; Iremiren, 1988; Joshi, 2004; Silva et al., 2004; Olabode et al., 2010; Jakusko et al., 2013), but these studies neither revealed the appropriate intra - row spacing of sesame, nor did it report the optimal frequency of weeding, particularly in a maizesesame intercrop. The experiment therefore aimed at evaluating the effects of intra-row spacing of sesame and frequency of weeding on yields of maize-sesame intercrop, with the objectives of identifying the appropriate intra - row spacing of sesame and the optimal frequency of weeding that will maximize intercropped yields of maize and sesame, as well as assess the advantages of the intercropping system.

\section{MATERIALS AND METHODS}

\subsection{Study location and varieties}

The experiment was carried out from July to October, during the cropping seasons in years 2012 and 2013, at the Research Farm of the University of Agriculture, Makurdi, Nigeria, to evaluate the effects of intra-row spacing of sesame and frequency of weeding on yields of maizesesame intercrop. The variety of maize used was 'Suwan SR' while that of sesame was 'E -8 '. The variety of both crops show good adaptation to the local environment and are popularly grown by farmers in the locality.

\subsection{Experimental area, design and treatments}

The experiment area $\left(513.0 \mathrm{~m}^{2}\right)$ which consisted of sandy-loam soil was ploughed, harrowed, ridged and divided into 44 plots. Each plot $\left(9.0 \mathrm{~m}^{2}\right)$ consisted of four ridges. The trial was a $3 \times 3$ factorial experiment, fitted in a randomized complete block design (RCBD), with four replications. Nine of the treatments consisted of intercropped maize with sesame sown at the intra-row spacing of $10 \mathrm{~cm}, 15 \mathrm{~cm}$ and $20 \mathrm{~cm}$, and at the varied weeding frequencies: maize-sesame intercrop sown on plots weeded once $(1 \mathrm{x})$ at 3 weeks after planting (WAP); maize-sesame intercrop sown on plots weeded twice $(2 \mathrm{x})$ at 3 and 6 WAP; maize-sesame intercrop sown on plots not weeded (NW). Sole sesame and sole maize, respectively sown at their recommended intra-row spacing of $10 \mathrm{~cm}$ and 30 $\mathrm{cm}$ (Iken and Amusa, 2004; Jakusko et al., 2013) and at their recommended weeding frequencies ( $2 \mathrm{x}$ at 3 and 6 WAP) constituted the tenth and eleventh treatments, which also served as the control plots.

\subsection{Crop arrangement and cultural attentions}

In the mixture, maize was sown in a single row, on top of the ridge, while sesame was sown by the side of the ridge, but at the different intra-row spacing and varied weeding frequencies. In the sole maize and sole sesame plots, seeds were sown about $2 \mathrm{~cm}$ deep, in a single row on top of ridge. The native hoe, which is the typical cultural hand hoeing method by farmers in the locality was used. The recommended rate of compound fertilizer NPK $(15: 15: 15)$ for sole maize: $100 \mathrm{Kg} \mathrm{N} \mathrm{ha}^{-1}$, $40 \mathrm{Kg} \mathrm{P} \mathrm{ha}^{-1}$ and $60 \mathrm{Kg} \mathrm{K} \mathrm{ha}^{-1}$; for sole sesame: $30 \mathrm{Kg} \mathrm{N} \mathrm{ha}^{-1}, 30 \mathrm{Kg} \mathrm{P} \mathrm{ha}^{-1}$ and $30 \mathrm{Kg} \mathrm{K} \mathrm{ha}^{-1}$ and 
for maize-sesame intercrop: $100 \mathrm{Kg} \mathrm{N} \mathrm{ha}^{-1}, 100 \mathrm{Kg} \mathrm{P}^{-1}$ and $100 \mathrm{Kg} \mathrm{K} \mathrm{ha}^{-1}$ were applied (Enwezor et al., 1989). The fertilizer was applied twice to each plot at 3 and 6 WAP.

\subsection{Harvesting, data and data analysis}

Maize was harvested at 12 WAP, when the leaves turned yellowish and fallen off, which were signs of senescence and cob maturity (Ijoyah and Jimba, 2012). Sesame was harvested when capsules turned yellowish with shedding of leaves (Ijoyah et al., 2014).

Data taken for maize include days to attain $50 \%$ flowering, plant height taken at $50 \%$ flowering (measured as the distance in $\mathrm{cm}$ from the soil surface to the tip of the topmost leaf), number of leaves per plant, number of cobs per plant, cob length $(\mathrm{cm})$, cob width (the width at the head, centre and tail ends were measured in $\mathrm{cm}$ and averaged). The cobs were weighed using an electronic weighing balance to obtain cob weight $(\mathrm{g})$. The cobs were later shelled manually and the total grains for each plot weighed to obtain the yield $\left(\mathrm{t} \mathrm{ha}^{-1}\right)$.

Data taken for sesame include days to attain $50 \%$ flowering, plant height $(\mathrm{cm})$ taken at maturity, number of branches per plant, number of capsules per plant, weight of capsule per plant, number of seeds per capsule and seed yield $\left(\mathrm{t} \mathrm{ha}^{-1}\right)$. All data were statistically analyzed using the Analysis of variance (ANOVA) for factorial experiment and the Least Significant Difference (LSD) was used for mean separation $(\mathrm{P} \leq 0.05)$ following the procedure of (Steel and Torrie, 1980).

The land equivalent ratio (LER) was determined as described by Willey (1985) using the formula:

$L E R=\frac{\text { Intercrop yield of crop } A}{\text { Sole crop yield of } A}+\frac{\text { Intercrop yield of crop } B}{\text { Sole crop yield of } B}$

The competitive ratio (CR) as described by Willey and Rao (1980) was determined using the formula:

$C R=L m / L s$, where; $L m$ : Partial LER for maize; $L s$ : Partial LER for sesame.

The percentage (\%) land saved as described by Willey (1985) using the formula:

$\%$ land saved $=100-1 /$ LER $X 100$

Aggressivity(A) gives a simple measure of how much the relative yield increase in component ' $a$ ' is greater than that for component ' $b$ ' as described by McGilchrist (1965) using the formula:

$A=\frac{\text { Mixture yield of }{ }^{\prime} a^{\prime}}{\text { Expected yield of }{ }^{\prime} a^{\prime}}-\frac{\text { Mixture yield of }{ }^{\prime} b^{\prime}}{\text { Expected yield of }{ }^{\prime} b^{\prime}}$

Where:

$\mathrm{A}=0$ : indicates that both crops are equally competitive; $\mathrm{A}=-$ : indicates dominated component

$\mathrm{A}=+$ : indicates dominant component

The land equivalent coefficient (LEC) as described by Adetiloye et al., (1983) was determined using the formula:

$L E C=L a \times L b$; where $L a: L E R$ of main crop; $L b: L E R$ of intercrop.

These calculations were used to assess the advantages of the intercropping system.

\section{RESULTS AND DISCUSSION}

\subsection{Yield and yield components of maize as affected by intra-row spacing of sesame and frequency of weeding.}

The main effects of intra-row spacing of sesame and frequency of weeding on yield and yield components of maize in a maize-sesame intercrop at Makurdi, Nigeria, during 2012 and 2013 cropping seasons is given in Table 1.

Days to attain $50 \%$ flowering for maize was neither affected by the varied intra-row spacing of sesame nor by the frequency of weeding, however, longer days was taken to attain $50 \%$ flowering for intercropped maize sown with sesame at the varied intra-row spacing and frequency of weeding as compared to that recorded for sole maize at its recommended intra-row spacing and frequency of weeding (Table 1). The intense overcrowding of the intercrops which might have induced competitive demands on available nutrients and moisture could have been responsible for prolonging days to attain $50 \%$ flowering for intercropped maize. 
Sole maize sown at its recommended intra-row spacing of $30 \mathrm{~cm}$ produced the highest plant height and highest number of leaves per plant as compared to those obtained from intercropped maize with sesame sown at the varied intra-row spacing (Table 1). These results agreed with that of Silwana and Lucas (2002) who reported that intercropping reduced the vegetative growth of component crops. Muoneke and Asiegbu (1997) also reported that high plant density of crops reduced number of leaves due to competition for light and other growth resources. Under intercropping, highest plant height and highest number of maize leaves were obtained from maize with sesame sown at the widest intra-row spacing of $20 \mathrm{~cm}$. The widest intra-row spacing of $20 \mathrm{~cm}$ for sesame could have enhanced a greater utilization of sunlight, thus producing more maize leaves. This result was similar to that of Saha et al., (2005) who reported a greater number of leaves at wider intra-row spacing of $40 \mathrm{~cm}$ as compared to that produced from reduced intra-row spacing of $20 \mathrm{~cm}$. Increasing weeding frequency correspondingly increased maize height (Table 1). The significant difference in maize height between intercropped maize sown on plots weeded once $(1 \mathrm{x})$ at 3 WAP and that weeded twice $(2 x)$ at 3 and 6 WAP could be attributed to a greater competition for growth resources, especially when weeding was done 1x at 3 WAP. Silva et al., (2004) reported that increase in weeding frequency facilitated the absorption of growth resources by crops. This view agreed with that of Joshi (2004), who reported that increased weeding regime, correspondingly increased height of plants. Number of maize leaves per plant was not significantly $(\mathrm{P} \leq 0.05)$ affected by the frequency of weeding (Table 1$)$.

Number of cobs produced from intercropped maize increased as intra-row spacing of sesame widens up to $20 \mathrm{~cm}$. The highest number of cobs was obtained from intercropped maize with sesame sown at the intra-row spacing of $20 \mathrm{~cm}$ (Table 1). This could be due to the more efficient use of basic resources achieved at wider spacing. This view agreed with that of Ogindo and Walker (2005) who reported that improvement of water use efficiency in intercropping leads to greater use of other resources. The intense overcrowding and subsequent competition for nutrients at closer intra-row spacing of sesame $(10 \mathrm{~cm}$ and $15 \mathrm{~cm})$ could have also influenced the reduction in the number of intercropped maize cobs per plant.

Though cob length and cob width were not significantly $(\mathrm{P} \leq 0.05)$ affected by the varied intrarow spacing of sesame, however, in both years, cob weight and maize yield produced from intercropped maize increased as intra-row spacing of sesame increased up to $20 \mathrm{~cm}$ (Table 1). Under intercropping, the highest yield was produced from maize sown with sesame at the intra-row spacing of $20 \mathrm{~cm}$. The highest number of cobs obtained from intercropped maize sown with sesame at the intra-row spacing of $20 \mathrm{~cm}$ could have been responsible for the highest maize yield. Yield of intercropped maize sown with sesame at the intra-row spacing of $20 \mathrm{~cm}$ was significantly $(\mathrm{P} \leq 0.05)$ higher than that obtained from intercropped maize sown with sesame at the intra-row spacing of 10 $\mathrm{cm}(13.8 \%$ and $18.6 \%$ respectively, in years 2012 and 2013) and significantly $(\mathrm{P} \leq 0.05)$ greater than that produced from intercropped maize sown with sesame at the intra-row spacing of $15 \mathrm{~cm}$ ( $7.7 \%$ and $9.3 \%$ respectively, in years 2012 and 2013). Number of cobs per plant, cob length, cob width and grain yield produced from intercropped maize sown on plots weeded twice $(2 x)$ at 3 and 6 WAP, were higher than those obtained from intercropped maize sown on plots weeded once $(1 \mathrm{x})$ at 3 WAP, and those produced from intercropped maize sown on plots not weeded (NW) (Table 1). Ibeawuchi et al., (2005) reported that components of yield can severely reduce by weed competition. In addition, the highest number of cobs produced from intercropped maize sown on plots weeded $2 x$ at 3 and 6 WAP, could have also accounted for its highest yield. In year 2012, yield produced from intercropped maize sown on plots weeded 2x at 3 and 6 WAP was significantly $(\mathrm{P} \leq 0.05)$ higher by $10.9 \%$ and $32.8 \%$ respectively, compared to that obtained from intercropped maize sown on plots weeded $1 \mathrm{x}$ at $3 \mathrm{WAP}$, and that produced from intercropped maize sown on plots NW, while in year 2013, it was higher by $9.3 \%$ and $23.2 \%$ respectively, compared to that obtained from plots weeded $1 \mathrm{x}$ at $3 \mathrm{WAP}$, and that produced from plots NW. 
Table 1. Main effects of intra-row spacing of sesame and frequency of weeding on yield and yield components of maize in a maize-sesame intercrop at Makurdi, Nigeria, during 2012 and 2013 cropping seasons

\begin{tabular}{|c|c|c|c|c|c|c|c|c|c|c|c|c|c|c|c|c|}
\hline \multirow[b]{3}{*}{ 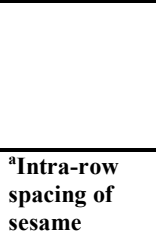 } & \multicolumn{2}{|c|}{$\begin{array}{c}\text { Days to } \\
\text { attain } \\
50 \% \\
\text { flowering }\end{array}$} & \multicolumn{2}{|c|}{$\begin{array}{c}\text { Maize plant } \\
\text { height }(\mathrm{cm}) \\
\text { at } 50 \% \\
\text { flowering }\end{array}$} & \multicolumn{2}{|c|}{$\begin{array}{c}\text { Number } \\
\text { of } \\
\text { leaves } \\
\text { per plant }\end{array}$} & \multicolumn{2}{|c|}{$\begin{array}{c}\text { Number of } \\
\text { cobs } \\
\text { per } \\
\text { plant }\end{array}$} & \multicolumn{2}{|c|}{$\begin{array}{c}\text { Cob } \\
\text { length } \\
(\mathrm{cm})\end{array}$} & \multicolumn{2}{|c|}{$\begin{array}{c}\text { Cob } \\
\text { width } \\
(\mathrm{cm})\end{array}$} & \multicolumn{2}{|c|}{$\begin{array}{c}\text { Cob } \\
\text { weight } \\
(\mathrm{kg})\end{array}$} & \multicolumn{2}{|c|}{$\begin{array}{l}\text { Yield } \\
\left(\mathrm{t} \mathrm{ha}^{-1}\right)\end{array}$} \\
\hline & 2012 & 22013 & 2012 & 2013 & 2012 & 2013 & 2012 & 2013 & 2012 & 2013 & 2012 & 2013 & 20122 & 2013 & 2012 & 2013 \\
\hline & & & & & & & & & & & & & & & & \\
\hline $\mathrm{SM}(30 \mathrm{~cm})$ & 49.2 & 50.0 & 148.6 & 145.2 & 15.3 & 14.2 & 2.82 & 2.3 & 25.2 & 27.4 & 15.6 & 16.8 & 0.40 & 0.38 & 1.86 & 1.79 \\
\hline $\mathrm{M}+\mathrm{S}(10 \mathrm{~cm})$ & 51.0 & 53.2 & 130.2 & 122.3 & 14.2 & 13.1 & 1.2 & 1.0 & 21.4 & 22.0 & 14.0 & 14.2 & 0.28 & 0.23 & 1.12 & 1.05 \\
\hline $\mathrm{M}+\mathrm{S}(15 \mathrm{~cm})$ & 51.8 & 53.1 & 134.5 & 128.2 & 14.5 & 13.6 & 1.81 & 1.3 & 22.0 & 24.8 & 14.4 & 14.7 & 0.32 & 0.25 & 1.20 & 1.17 \\
\hline $\mathrm{M}+\mathrm{S}(20 \mathrm{~cm})$ & 51.2 & 53.0 & 144.0 & 142.1 & 14.8 & 14.4 & 2.51 & 1.7 & 24.8 & 26.4 & 15.2 & 15.8 & 0.35 & 0.29 & 1.30 & 1.29 \\
\hline $\operatorname{LSD}(\mathrm{P} \leq 0.05)$ & 5.2 & 6.4 & 3.6 & 5.3 & 0.2 & 0.4 & 0.50 & 0.2 & 6.1 & 8.2 & 3.5 & 6.2 & 0.04 & 0.02 & 0.04 & 0.06 \\
\hline $\begin{array}{l}\text { brequency } \\
\text { of weeding }\end{array}$ & & & & & & & & & & & & & & & & \\
\hline $\operatorname{SM}(2 X)$ & 52.2 & 52.7 & 122.5 & 124.2 & 10.8 & 11.2 & 1.1 & 1.2 & 15.5 & 16.8 & 10.2 & 10.4 & 0.40 & 0.47 & 2.40 & 2.42 \\
\hline $\mathrm{M}+\mathrm{S}(1 \mathrm{X})$ & 52.9 & 53.7 & 134.0 & 137.7 & 11.4 & 11.8 & 1.0 & 1.1 & 14.3 & 15.2 & 9.0 & 10.2 & 0.25 & 0.22 & 2.12 & 2.15 \\
\hline$M+S(2 X)$ & 53.0 & 53.7 & 150.1 & 155.4 & 12.7 & 13.0 & 1.3 & 1.2 & 15.7 & 16.9 & 11.1 & 11.6 & 0.38 & 0.43 & 2.38 & 2.37 \\
\hline $\mathrm{M}+\mathrm{S}(\mathrm{NW})$ & 54.8 & 55.7 & 98.3 & 109.6 & 10.0 & 10.5 & 1.0 & 1.0 & 11.2 & 13.5 & 8.2 & 9.4 & 0.10 & 0.12 & 1.60 & 1.82 \\
\hline $\operatorname{LSD}(\mathrm{P} \leq 0.05)$ & 4.7 & 6.3 & 8.6 & 10.2 & 5.4 & 7.2 & 0.04 & 0.01 & 1.2 & 1.4 & 1.8 & 1.2 & 0.07 & 0.05 & 0.20 & 0.40 \\
\hline $\mathrm{Cv}(\%)^{\mathrm{a}}$ & 15.2 & 10.2 & 12.0 & 8.4 & 11.3 & 9.8 & 10.4 & 15.2 & 12.3 & 8.6 & 20.4 & 14.8 & 9.6 & 11.7 & 15.8 & 13.2 \\
\hline $\mathrm{Cv}(\%)^{\mathrm{b}}$ & 10.8 & 18.4 & 10.3 & 12.4 & 16.8 & 20.2 & 10.2 & 12.4 & 5.6 & 4.4 & 12.2 & 8.4 & 10.4 & 15.2 & 5.3 & 9.2 \\
\hline
\end{tabular}

sesame sown at the intra-row spacing of $15 \mathrm{~cm} ., \mathbf{M}+\mathbf{S}(\mathbf{2 0} \mathbf{~ c m})$ : maize with sesame sown at the intra-row spacing of $20 \mathrm{~cm} . \mathbf{S M}(\mathbf{2 X})$ : sole maize sown on plots weeded twice at 3 and 6 WAP., M+S (1 X): maize-sesame intercrop sown on plots weeded once at 3 WAP.,M+S (2 X): maize-sesame intercrop sown on plots weeded twice at 3 and 6 WAP., $\mathbf{M}+\mathbf{S}$ (NW): maize-sesame intercrop sown on plots not weeded, WAP: weeks after planting.,

Cv: coefficient of variance.

\subsection{Yield and yield components of sesame as affected by intra-row spacing of sesame and frequency of weeding.}

The main effects of intra-row spacing of sesame and frequency of weeding on yield and yield components of sesame in a maize-sesame intercrop at Makurdi, Nigeria during 2012 and 2013 cropping seasons is shown in Table 2. Increasing intra-row spacing of sesame up to $20 \mathrm{~cm}$ did not significantly $(\mathrm{P} \leq 0.05)$ affect days to attain $50 \%$ flowering for sesame (Table 2$)$. Days to attain 50 $\%$ flowering occurred earliest for sole sesame at its recommended frequency of weeding ( $2 \mathrm{x}$ at 3 and 6 WAP), while days to attain $50 \%$ flowering was delayed for intercropped sesame sown on plots NW (Table 2). The intense overcrowding of the intercrops could have prompted competitive demands on available nutrients and moisture, thus prolonging days to attain $50 \%$ flowering for all intercropped sesame, irrespective of weeding frequency as compared to sole cropping of sesame.

Sole sesame sown at its recommended intra-row spacing of $10 \mathrm{~cm}$ gave the highest plant height and highest number of branches at maturity (Table 2). Sole sesame could have benefitted maximally from the available growth resources, thereby producing the tallest plant height and highest number of branches per plant at maturity. Under intercropping, sesame sown at the intra-row spacing of 20 $\mathrm{cm}$ produced the tallest plant height and highest number of branches per plant at maturity (Table 2). Plant height of intercropped sesame was highest $(173.1 \mathrm{~cm}$ and $176.0 \mathrm{~cm}$, respectively, in years 2012 and 2013), when weeding was done 2x at 3 and 6 WAP. Mubarak (2004) reported that such increased weed removal may increase crop height, partly by enhancing aeration and water movement in soil. Irrespective of the frequency of weeding, number of branches per plant at maturity, obtained from intercropped sesame was lower than that produced from sole sesame at its recommended frequency of weeding. Shading by taller intercropped maize plants could have reduced the photosynthetic absorption rate for sesame, thereby reducing number of branches at maturity. This view supports that of Silwana and Lucas (2002) who reported that intercropping reduced vegetative growth of component crops.

Increasing intra-row spacing of intercropped sesame up to $20 \mathrm{~cm}$ progressively increased number of capsules per plant (Table 2). This could be attributed to the reduced inter-specific competition for growth resources at wider intra-row spacing. In addition, the highest number of branches per plant produced from intercropped sesame sown at the intra-row spacing of $20 \mathrm{~cm}$ could have also been responsible for the highest number of capsules per plant. Under intercropping, the highest number of capsules per plant was obtained from intercropped sesame sown on plots 
weeded $2 x$ at 3 and 6 WAP. The greater conservation of water by soil prompted by the increased frequency of weeding could explain the result. Suleiman (2005) reported that the number of calyces per roselle plant increased with increased level of weeding. Sole sesame sown at its recommended intra-row spacing of $10 \mathrm{~cm}$ produced a higher weight of capsule per plant, higher number of seeds per capsule and greater seed yield as compared to those obtained from intercropped sesame sown at the varied intra-row spacing. Shading by taller maize plants in intercrop might have prompted a reduction in the photosynthetic absorption rate of sesame, thus, reducing capsule weight, number of seeds per capsule and seed yield. Higher yield in sole cropping over intercropping have also been reported by Olufajo (1992) and Muneer et al., (2004). Intercropped sesame sown at the intra-row spacing of $20 \mathrm{~cm}$ produced the highest capsule weight, highest number of seeds per capsule and highest sesame yield (Table 2). The highest number of branches per plant and the highest number of capsules per plant produced from intercropped sesame sown at the intra-row spacing of $20 \mathrm{~cm}$ could have contributed to its highest capsule weight and yield. Yield of intercropped sesame sown at the intra-row spacing of $20 \mathrm{~cm}$ was significantly $(\mathrm{P} \leq 0.05)$ higher than that obtained from intercropped sesame sown at the intra-row spacing of $10 \mathrm{~cm}(23.5 \%$ and $21.4 \%$ respectively, in years 2012 and 2013) and significantly $(\mathrm{P} \leq 0.05)$ higher than that produced from intercropped sesame sown at the intra-row spacing of $15 \mathrm{~cm}(14.7 \%$ and $17.9 \%$ respectively, in years 2012 and 2013). Under intercropping, the highest capsule weight per plant, highest number of seeds per capsule and highest sesame yield were obtained from intercropped sesame sown on plots weeded $2 \mathrm{x}$ at 3 and $6 \mathrm{WAP}$. The highest number of capsules produced could be responsible for the greatest capsule weight, highest number of seeds per capsule and highest seed yield. Yield obtained from intercropped sesame sown on plots weeded $2 \mathrm{x}$ at 3 and 6 WAP, was significantly $(\mathrm{P} \leq 0.05)$ higher than that produced from intercropped sesame sown on plots weeded $1 \mathrm{x}$ at 3 WAP $(20.6 \%$ and 31.8 $\%$ respectively, in 2012 and 2013) and significantly $(\mathrm{P} \leq 0.05)$ higher than that obtained from intercropped sesame sown on plots NW (61.8\% and 59.1\% respectively, in years 2012 and 2013).

Table 2. Main effects of intra-row spacing of sesame and frequency of weeding on yield and yield components of sesame in a maize - sesame intercrop, at Makurdi, Nigeria, during 2012 and 2013 cropping seasons

\begin{tabular}{|c|c|c|c|c|c|c|c|c|c|c|c|c|c|c|}
\hline & \multicolumn{2}{|c|}{$\begin{array}{c}\text { Days to } \\
\text { attain } \\
50 \% \\
\text { flowering }\end{array}$} & \multicolumn{2}{|c|}{$\begin{array}{c}\text { Sesame plant } \\
\text { height }(\mathrm{cm}) \\
\text { at } 50 \% \\
\text { maturity }\end{array}$} & \multicolumn{2}{|c|}{$\begin{array}{c}\text { Number } \\
\text { of branches } \\
\text { per plant } \\
\text { at maturity }\end{array}$} & \multicolumn{2}{|c|}{$\begin{array}{c}\text { Number of } \\
\text { capsules } \\
\text { per } \\
\text { plant }\end{array}$} & \multicolumn{2}{|c|}{$\begin{array}{l}\text { Weight of } \\
\text { capsules } \\
\text { per plant } \\
(\mathrm{kg})\end{array}$} & \multicolumn{2}{|c|}{$\begin{array}{l}\text { Number } \\
\text { of } \\
\text { seeds } \\
\text { per capsule }\end{array}$} & \multicolumn{2}{|c|}{$\begin{array}{l}\text { Seed } \\
\text { yield } \\
\left(\mathrm{t} \mathrm{ha}^{-1}\right)\end{array}$} \\
\hline & 2012 & 2013 & 2012 & 2013 & 2012 & 2013 & 2012 & 2013 & 2013 & & 2012 & 2013 & 2012 & 2013 \\
\hline \multicolumn{15}{|l|}{$\begin{array}{l}{ }^{\text {a Intra-row }} \\
\text { spacing of } \\
\text { sesame }\end{array}$} \\
\hline $\mathrm{SS}(10 \mathrm{~cm})$ & 64.6 & 65.8 & 180.6 & 177.2 & 11.3 & 10.5 & 48.2 & 45.6 & 0.62 & 0.56 & 43.7 & 42.6 & 0.35 & 0.30 \\
\hline $\mathrm{M}+\mathrm{S}(10 \mathrm{~cm})$ & 64.2 & 65.0 & 140.2 & 123.4 & 8.4 & 8.2 & 33.4 & 30.9 & 0.43 & 0.30 & 41.0 & 39.3 & 0.26 & 0.22 \\
\hline $\mathrm{M}+\mathrm{S}(15 \mathrm{~cm})$ & 65.8 & 65.0 & 148.7 & 141.2 & 9.4 & 8.7 & 36.8 & 33.2 & 0.51 & 0.40 & 41.9 & 39.5 & 0.29 & 0.23 \\
\hline $\mathrm{M}+\mathrm{S}(20 \mathrm{~cm})$ & 64.9 & 65.3 & 173.3 & 165.9 & 10.8 & 9.2 & 40.1 & 37.7 & 0.60 & 0.52 & 42.1 & 42.0 & 0.34 & 0.28 \\
\hline $\operatorname{LSD}(\mathrm{P} \leq 0.05)$ & 4.6 & 3.2 & 5.1 & 10.4 & 0.5 & 0.3 & 2.0 & 1.2 & 0.08 & 0.05 & 0.5 & 0.3 & 0.02 & 0.01 \\
\hline \multicolumn{15}{|l|}{$\begin{array}{l}{ }^{\text {b}} \text { Frequency of } \\
\text { weeding }\end{array}$} \\
\hline $\operatorname{SS}(2 X)$ & 64.2 & 64.5 & 182.2 & 180.4 & 12.3 & 12.5 & 43.2 & 43.6 & 0.60 & 0.64 & 46.4 & 44.3 & 0.33 & 0.35 \\
\hline $\mathrm{M}+\mathrm{S}(1 \mathrm{X})$ & 67.9 & 67.0 & 162.4 & 166.3 & 11.2 & 11.4 & 31.2 & 31.4 & 0.53 & 0.55 & 35.2 & 34.4 & 0.27 & 0.30 \\
\hline $\mathrm{M}+\mathrm{S}(2 \mathrm{X})$ & 65.8 & 66.8 & 173.1 & 176.0 & 11.7 & 12.0 & 42.0 & 42.9 & 0.58 & 0.63 & 46.1 & 46.7 & 0.34 & 0.44 \\
\hline $\mathrm{M}+\mathrm{S}(\mathrm{NW})$ & 70.2 & 69.0 & 136.5 & 139.0 & 9.1 & 9.4 & 21.1 & 21.3 & 0.34 & 0.36 & 25.2 & 23.0 & 0.13 & 0.18 \\
\hline $\operatorname{LSD}(\mathrm{P} \leq 0.05)$ & 1.3 & 2.2 & 3.0 & 4.4 & 0.3 & 0.2 & 6.0 & 5.3 & 0.03 & 0.05 & 5.2 & 7.0 & 0.02 & 0.01 \\
\hline $\mathrm{Cv}(\%)^{\mathrm{a}}$ & 12.8 & 15.4 & 10.7 & 18.2 & 8.3 & 10.5 & 15.8 & 12.4 & 18.2 & 9.6 & 13.4 & 8.7 & 10.6 & 12.2 \\
\hline $\mathrm{Cv}(\%)^{\mathrm{b}}$ & 15.4 & 10.2 & 5.6 & 9.8 & 10.4 & 12.6 & 12.5 & 14.0 & 6.8 & 8.4 & 18.5 & 10.5 & 10.3 & 14.7 \\
\hline
\end{tabular}

SS (10cm): sole sesame sown at the recommended intra-row spacing of $10 \mathrm{~cm} ., \mathbf{M}+\mathbf{S}(\mathbf{1 0} \mathbf{c m})$ : maize with sesame sown at the intra-row spacing of $10 \mathrm{~cm} ., \mathbf{M}+\mathbf{S}(\mathbf{1 5} \mathbf{~ c m})$ : maize with sesame sown at the intra-row spacing of $15 \mathrm{~cm}$., $\mathbf{M}+\mathbf{S} \mathbf{( 2 0} \mathbf{~ c m})$ : maize with sesame sown at the intra-row spacing of $20 \mathrm{~cm}$.,SS (2X): sole sesame sown on plots weeded twice at 3 and 6 WAP., M+S (1 X): maize-sesame intercrop sown on plots weeded once at 3 WAP.,M+S (2 X): maize-sesame intercrop sown on plots weeded twice at 3 and 6 WAP., $\mathbf{M}+\mathbf{S}$ (NW): maize-sesame intercrop sown on plots not weeded, WAP: weeks after planting., Cv: coefficient of variance.

\subsection{Interaction of intra-row spacing of sesame $x$ frequency of weeding on yield and yield components of maize.}

Though, the interaction of intra-row spacing $\mathrm{x}$ frequency of weeding did not significantly $(\mathrm{P} \leq 0.05)$ affect days to attain $50 \%$ flowering for maize, number of leaves per plant, number of cobs 
per plant (Table 3), cob length and cob width (Table 4), however, the highest cob weight and highest maize yield were produced from intercropped maize with sesame sown at the intra-row spacing of $20 \mathrm{~cm}$, on plots weeded 2x at 3 and 6 WAP (Table 4). The tallest maize plants produced at this level of treatment could have contributed to the highest cob weight and highest maize yield. This view supports Moniruzzaman et al., (2007) who observed a correlation between plant height and yield of okra.

Table 3. Interaction of intra-row spacing of sesame $\mathrm{x}$ frequency of weeding on days to attain $50 \%$ flowering for maize, maize plant height $(\mathrm{cm})$ at $50 \%$ flowering, number of maize leaves per plant and number of cobs per plant at Makurdi, Nigeria, during 2012 and 2013 cropping seasons

\begin{tabular}{|c|c|c|c|c|c|c|c|c|c|}
\hline \multirow[t]{2}{*}{$\begin{array}{l}\text { Intra-row } \\
\text { spacing } \\
\text { of sesame }\end{array}$} & \multirow[t]{2}{*}{$\begin{array}{c}\text { Frequency } \\
\text { of } \\
\text { weeding }\end{array}$} & \multicolumn{2}{|c|}{$\begin{array}{c}\text { Days to } \\
\text { attain } \\
50 \% \\
\text { flowering }\end{array}$} & \multicolumn{2}{|c|}{$\begin{array}{c}\text { Maize } \\
\text { plant height } \\
(\mathrm{cm}) \text { at } \\
50 \% \text { flowering }\end{array}$} & \multicolumn{2}{|c|}{$\begin{array}{l}\text { Number } \\
\text { of leaves } \\
\text { per plant }\end{array}$} & \multicolumn{2}{|c|}{$\begin{array}{l}\text { Number } \\
\text { of cobs } \\
\text { per plant }\end{array}$} \\
\hline & & 2012 & 2013 & 2012 & 2013 & 2012 & 2013 & 2012 & 2013 \\
\hline \multirow{3}{*}{$M+S(10 \mathrm{~cm})$} & $1 \mathrm{X}$ & 52.8 & 52.6 & 130.1 & 131.3 & 11.2 & 11.0 & 1.9 & 1.7 \\
\hline & $2 x$ & 53.1 & 53.2 & 136.2 & 134.2 & 12.0 & 11.4 & 2.0 & 2.2 \\
\hline & NW & 53.4 & 54.2 & 120.1 & 122.3 & 8.5 & 8.8 & 1.2 & 1.4 \\
\hline \multirow{3}{*}{$M+S(15 \mathrm{~cm})$} & $1 \mathrm{X}$ & 52.3 & 52.3 & 130.3 & 132.2 & 10.5 & 10.3 & 1.7 & 1.5 \\
\hline & $2 X$ & 53.3 & 53.0 & 142.8 & 144.1 & 12.3 & 12.0 & 2.2 & 2.0 \\
\hline & NW & 54.5 & 54.4 & 124.2 & 120.2 & 9.6 & 9.2 & 1.0 & 1.2 \\
\hline \multirow[t]{4}{*}{$\mathrm{M}+\mathrm{S}(20 \mathrm{~cm})$} & $1 \mathrm{X}$ & 53.2 & 53.1 & 146.0 & 144.0 & 13.0 & 12.8 & 1.8 & 1.6 \\
\hline & $2 X$ & 53.4 & 53.5 & 150.3 & 153.1 & 14.7 & 14.3 & 2.4 & 2.3 \\
\hline & NW & 54.2 & 54.3 & 125.5 & 130.2 & 9.8 & 10.0 & 1.0 & 1.0 \\
\hline & LSD $(\mathrm{P} \leq 0.05)$ & 4.7 & 5.1 & 5.2 & 4.8 & 9.2 & 8.7 & 3.6 & 4.1 \\
\hline
\end{tabular}

$\mathbf{M}+\mathbf{S}(\mathbf{1 0} \mathbf{~ c m}) \mathbf{1 X}$ : maize with sesame sown at the intra-row spacing of $10 \mathrm{~cm}$ on plot weeded once at $3 \mathrm{WAP}$., $\mathbf{M}+\mathbf{S}(\mathbf{1 0} \mathbf{~ c m}) \mathbf{2 X}$ : maize with sesame sown at the intra-row spacing of $10 \mathrm{~cm}$ on plot weeded twice at 3 and 6 WAP., $\mathbf{M}+\mathbf{S}(\mathbf{1 0} \mathbf{~ c m}) \mathbf{N W}$ : maize with sesame sown at the intra-row spacing of $10 \mathrm{~cm}$ on plot not weeded.

$\mathbf{M}+\mathbf{S}(\mathbf{1 5} \mathbf{~ c m}) \mathbf{1 X}$ : maize with sesame sown at the intra-row spacing of $15 \mathrm{~cm}$ on plot weeded once at $3 \mathrm{WAP} ., \mathbf{M}+\mathbf{S}(\mathbf{1 5} \mathrm{cm}) \mathbf{2 X}$ : maize with sesame sown at the intra-row spacing of $15 \mathrm{~cm}$ on plot weeded twice at 3 and 6 WAP., $\mathbf{M}+\mathbf{S}(\mathbf{1 5} \mathbf{~ c m}) \mathbf{N W}$ : maize with sesame sown at the intra-row spacing of $15 \mathrm{~cm}$ on plot not weeded.

$\mathbf{M}+\mathbf{S}(\mathbf{2 0} \mathbf{~ c m}) \mathbf{1 X}$ : maize with sesame sown at the intra-row spacing of $20 \mathrm{~cm}$ on plot weeded once at 3 WAP., $\mathbf{M}+\mathbf{S}(\mathbf{2 0} \mathbf{c m}) \mathbf{2 X}$ : maize with sesame sown at the intra-row spacing of $20 \mathrm{~cm}$ on plot weeded twice at 3 and 6 WAP., $\mathbf{M}+\mathbf{S}(\mathbf{2 0} \mathbf{~ c m}) \mathbf{N W}$ : maize with sesame sown at the intra-row spacing of $20 \mathrm{~cm}$ on plot not weeded., WAP: weeks after planting.,

Table 4. Interaction of intra-row spacing of sesame $x$ frequency of weeding on cob length, cob width, cob weight and yield of maize at Makurdi, Nigeria, during 2012 and 2013 cropping seasons

\begin{tabular}{|c|c|c|c|c|c|c|c|c|c|}
\hline \multirow[t]{2}{*}{$\begin{array}{l}\text { Intra-row spacing } \\
\text { of sesame }\end{array}$} & \multirow[t]{2}{*}{$\begin{array}{l}\text { Frequency of } \\
\text { weeding }\end{array}$} & \multicolumn{2}{|c|}{$\begin{array}{c}\text { Cob } \\
\text { length } \\
(\mathrm{cm})\end{array}$} & \multicolumn{2}{|c|}{$\begin{array}{c}\text { Cob } \\
\text { width } \\
(\mathrm{cm})\end{array}$} & \multicolumn{2}{|c|}{$\begin{array}{c}\text { Cob } \\
\text { weight } \\
(\mathrm{kg})\end{array}$} & \multicolumn{2}{|c|}{$\begin{array}{l}\text { Yield } \\
\left(\mathrm{t} \mathrm{ha}^{-1}\right)\end{array}$} \\
\hline & & 2012 & 2013 & 2012 & 2013 & 2012 & 2013 & 2012 & 2013 \\
\hline \multirow{3}{*}{$M+S(10 \mathrm{~cm})$} & $1 \mathrm{X}$ & 19.3 & 19.0 & 10.4 & 10.6 & 0.24 & 0.20 & 1.20 & 1.22 \\
\hline & $2 X$ & 20.1 & 20.3 & 11.6 & 12.0 & 0.28 & 0.24 & 1.26 & 1.24 \\
\hline & NW & 18.3 & 17.5 & 9.4 & 9.0 & 0.15 & 0.13 & 0.65 & 0.60 \\
\hline \multirow{3}{*}{$\mathrm{M}+\mathrm{S}(15 \mathrm{~cm})$} & $1 \mathrm{X}$ & 22.0 & 22.2 & 10.5 & 10.0 & 0.27 & 0.24 & 1.25 & 1.23 \\
\hline & $2 X$ & 23.2 & 21.0 & 11.8 & 10.4 & 0.30 & 0.26 & 1.30 & 1.28 \\
\hline & NW & 18.4 & 18.7 & 10.2 & 10.4 & 0.18 & 0.16 & 0.70 & 0.72 \\
\hline \multirow[t]{4}{*}{$M+S(20 \mathrm{~cm})$} & $1 \mathrm{X}$ & 22.3 & 22.0 & 11.7 & 11.9 & 0.33 & 0.20 & 1.27 & 1.25 \\
\hline & $2 X$ & 24.6 & 24.8 & 12.2 & 13.0 & 0.38 & 0.35 & 1.32 & 1.35 \\
\hline & NW & 23.1 & 23.2 & 9.5 & 10.4 & 0.20 & 0.18 & 0.82 & 0.80 \\
\hline & $\operatorname{LSD}(\mathrm{P} \leq 0.05)$ & 9.6 & 10.4 & 6.2 & 8.3 & 0.06 & 0.04 & 0.05 & 0.03 \\
\hline
\end{tabular}

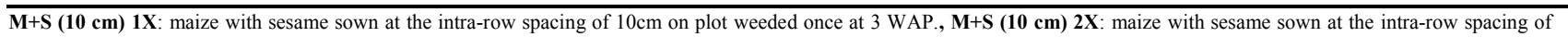
$10 \mathrm{~cm}$ on plot weeded twice at 3 and 6 WAP., $\mathbf{M}+\mathbf{S}(\mathbf{1 0} \mathbf{~ c m}) \mathbf{N W}$ : maize with sesame sown at the intra-row spacing of $10 \mathrm{~cm}$ on plot not weeded.

$\mathbf{M}+\mathbf{S}(\mathbf{1 5} \mathbf{~ c m}) \mathbf{1 X}$ : maize with sesame sown at the intra-row spacing of $15 \mathrm{~cm}$ on plot weeded once at 3 WAP., $\mathbf{M}+\mathbf{S}(\mathbf{1 5} \mathbf{~ c m}) \mathbf{2 X}$ : maize with sesame sown at the intra-row spacing of $15 \mathrm{~cm}$ on plot weeded twice at 3 and 6 WAP., $\mathbf{M}+\mathbf{S}(\mathbf{1 5} \mathbf{~ c m ) ~ N W : ~ m a i z e ~ w i t h ~ s e s a m e ~ s o w n ~ a t ~ t h e ~ i n t r a - r o w ~ s p a c i n g ~ o f ~} 15 \mathrm{~cm}$ on plot not weeded.

$\mathbf{M}+\mathbf{S}(\mathbf{2 0} \mathbf{~ c m}) \mathbf{1 X}$ : maize with sesame sown at the intra-row spacing of $20 \mathrm{~cm}$ on plot weeded once at 3 WAP., $\mathbf{M}+\mathbf{S}(\mathbf{2 0} \mathbf{~ c m ) ~} \mathbf{2 X}$ : maize with sesame sown at the intra-row spacing of $20 \mathrm{~cm}$ on plot weeded twice at 3 and 6 WAP., $\mathbf{M}+\mathbf{S}(\mathbf{2 0} \mathbf{~ c m}) \mathbf{N W}$ : maize with sesame sown at the intra-row spacing of $20 \mathrm{~cm}$ on plot not weeded., WAP: weeks after planting. 


\subsection{Interaction of intra-row spacing of sesame $x$ frequency of weeding on yield and yield components of sesame.}

Days taken to attain $50 \%$ flowering for sesame was not significantly $(\mathrm{P} \leq 0.05)$ affected by the interaction of intra-row spacing $\mathrm{x}$ frequency of weeding (Table 5), but the tallest sesame plant, highest number of branches per plant, highest number of capsule per plant, highest number of seeds per capsule and highest seed yield were obtained from intercropped sesame sown at the intra-row spacing of $20 \mathrm{~cm}$, on plots weeded $2 \mathrm{x}$ at 3 and 6 WAP (Table 5).

Table 5. Interaction of intra-row spacing of sesame $x$ frequency of weeding on yield and yield components of sesame at Makurdi, Nigeria, during 2012 and 2013 cropping seasons

\begin{tabular}{|c|c|c|c|c|c|c|c|c|c|c|c|c|c|c|c|}
\hline \multirow[t]{2}{*}{$\begin{array}{l}\text { Intra-row } \\
\text { spacing } \\
\text { of sesame }\end{array}$} & \multirow[t]{2}{*}{$\begin{array}{l}\text { Frequency } \\
\text { of } \\
\text { weeding }\end{array}$} & \multicolumn{2}{|c|}{$\begin{array}{c}\text { Days to } \\
\text { attain } \\
50 \% \\
\text { flowering }\end{array}$} & \multicolumn{2}{|c|}{$\begin{array}{c}\text { Sesame plant } \\
\text { height }(\mathrm{cm}) \\
\text { at } 50 \% \\
\text { flowering }\end{array}$} & \multicolumn{2}{|c|}{$\begin{array}{l}\begin{array}{c}\text { Number } \\
\text { of } \\
\text { branches } \\
\text { per plant }\end{array} \\
\end{array}$} & \multicolumn{2}{|c|}{$\begin{array}{l}\text { Number } \\
\text { of } \\
\text { capsule } \\
\text { per plant }\end{array}$} & \multicolumn{2}{|c|}{$\begin{array}{c}\text { Weight of } \\
\text { capsules } \\
\text { per plant } \\
(\mathrm{kg}) \\
\end{array}$} & \multicolumn{2}{|c|}{$\begin{array}{c}\text { Number } \\
\text { of seeds } \\
\text { per capsule }\end{array}$} & \multicolumn{2}{|c|}{$\begin{array}{c}\text { Seed } \\
\text { yield } \\
\left(\mathrm{t} \mathrm{ha}^{-1}\right)\end{array}$} \\
\hline & & 2012 & 2013 & 2012 & 2013 & 2012 & 2013 & 2012 & 2013 & 2012 & 2013 & 2012 & 2013 & 2012 & 2013 \\
\hline \multirow{3}{*}{$M+S(10 \mathrm{~cm})$} & $1 \mathrm{X}$ & 64.2 & 64.4 & 150.4 & 152.5 & 10.5 & 10.7 & 32.1 & 31.8 & 0.50 & 0.43 & 39.0 & 36.3 & 0.25 & 0.22 \\
\hline & $2 X$ & 64.0 & 64.2 & 155.2 & 157.2 & 12.3 & 12.8 & 33.7 & 31.6 & 0.58 & 0.56 & 42.1 & 43.4 & 0.30 & 0.32 \\
\hline & NW & 65.6 & 64.9 & 130.3 & 132.0 & 9.0 & 9.2 & 20.1 & 22.4 & 0.34 & 0.30 & 28.0 & 26.3 & 0.10 & 0.12 \\
\hline \multirow{3}{*}{$\mathrm{M}+\mathrm{S}(15 \mathrm{~cm})$} & $1 \mathrm{X}$ & 63.9 & 63.4 & 155.0 & 154.2 & 11.1 & 10.6 & 33.5 & 30.9 & 0.59 & 0.56 & 39.8 & 42.2 & 0.29 & 0.27 \\
\hline & $2 X$ & 64.7 & 65.2 & 158.0 & 157.6 & 12.0 & 11.8 & 36.8 & 35.4 & 0.65 & 0.63 & 44.2 & 45.0 & 0.36 & 0.35 \\
\hline & NW & 65.9 & 65.7 & 132.4 & 134.0 & 9.2 & 9.6 & 25.2 & 23.0 & 0.30 & 0.32 & 30.2 & 28.6 & 0.12 & 0.15 \\
\hline \multirow{4}{*}{$\mathrm{M}+\mathrm{S}(20 \mathrm{~cm})$} & $1 \mathrm{X}$ & 64.8 & 64.5 & 160.4 & 162.5 & 11.5 & 11.9 & 36.2 & 32.3 & 0.66 & 0.62 & 40.7 & 43.0 & 0.32 & 0.35 \\
\hline & $2 X$ & 63.6 & 64.6 & 165.0 & 168.2 & 13.7 & 13.9 & 41.8 & 40.0 & 0.78 & 0.73 & 48.2 & 49.3 & 0.48 & 0.45 \\
\hline & NW & 65.2 & 65.5 & 135.6 & 132.3 & 8.7 & 8.4 & 30.1 & 32.4 & 0.32 & 0.30 & 28.3 & 30.0 & 0.18 & 0.20 \\
\hline & $\operatorname{LSD}(\mathrm{P} \leq 0.05)$ & 6.3 & 7.1 & 8.5 & 7.2 & 0.8 & 0.5 & 2.4 & 5.1 & 0.06 & 0.03 & 3.0 & 5.2 & 0.05 & 0.08 \\
\hline
\end{tabular}

$\mathbf{M}+\mathbf{S}(\mathbf{1 0} \mathbf{~ c m}) \mathbf{1 X}$ : maize with sesame sown at the intra-row spacing of $10 \mathrm{~cm}$ on plot weeded once at $3 \mathrm{WAP}$., $\mathbf{M}+\mathbf{S}(\mathbf{1 0} \mathbf{~ c m}) \mathbf{2 X}$ : maize with sesame sown at the intra-row spacing of $10 \mathrm{~cm}$ on plot weeded twice at 3 and 6 WAP., $\mathbf{M}+\mathbf{S}(\mathbf{1 0} \mathbf{~ c m}) \mathbf{N W}$ : maize with sesame sown at the intra-row spacing of $10 \mathrm{~cm}$ on plot not weeded.

$\mathbf{M}+\mathbf{S}(\mathbf{1 5} \mathbf{~ c m}) \mathbf{1 X}$ : maize with sesame sown at the intra-row spacing of $15 \mathrm{~cm}$ on plot weeded once at 3 WAP., $\mathbf{M}+\mathbf{S}(\mathbf{1 5} \mathbf{~ c m}) \mathbf{2 X}$ : maize with sesame sown at the intra-row spacing of $15 \mathrm{~cm}$ on plot weeded twice at 3 and 6 WAP., $\mathbf{M}+\mathbf{S}(\mathbf{1 5} \mathbf{~ c m}) \mathbf{N W}$ : maize with sesame sown at the intra-row spacing of $15 \mathrm{~cm}$ on plot not weeded.

$\mathbf{M}+\mathbf{S}(\mathbf{2 0} \mathbf{~ c m}) \mathbf{1 X}$ : maize with sesame sown at the intra-row spacing of $20 \mathrm{~cm}$ on plot weeded once at 3 WAP., $\mathbf{M}+\mathbf{S}(\mathbf{2 0} \mathbf{~ c m}) \mathbf{2 X}$ : maize with sesame sown at the intra-row spacing of $20 \mathrm{~cm}$ on plot weeded twice at 3 and 6 WAP., $\mathbf{M}+\mathbf{S}(\mathbf{2 0} \mathbf{~ c m}) \mathbf{N W}$ : maize with sesame sown at the intra-row spacing of $20 \mathrm{~cm}$ on plot not weeded., WAP: weeks after planting.

\subsection{Evaluation of intercropping advantages of maize and sesame as affected by intra-row spacing of sesame and frequency of weeding.}

The total intercrop yields at the different intra-row spacing of sesame and at the varied frequency of weeding were higher than the intercrop yields produced from each intra-row spacing and frequency of weeding (Table 6). The highest total intercrop yield was obtained from the maizesesame intercropping system with sesame sown at the intra-row spacing of $20 \mathrm{~cm}$, on plots weeded $2 \mathrm{x}$ at 3 and 6 WAP (Table 6). 
Table 6. Yields of maize and sesame, intercrop yields and total intercrop yield as influenced by intra-row spacing of sesame and frequency of weeding in a maize-sesame intercrop at Makurdi, Nigeria, during 2012 and 2013 cropping seasons

\begin{tabular}{|c|c|c|c|c|}
\hline \multicolumn{2}{|c|}{$\begin{array}{c}\text { Sole crop yields } \\
\left(\mathrm{t} \mathrm{ha}^{-1}\right)\end{array}$} & \multicolumn{2}{|c|}{$\begin{array}{l}\text { Intercrop yields } \\
\left(\mathrm{t} \mathrm{ha}^{-1}\right)\end{array}$} & \multirow{2}{*}{$\begin{array}{c}\text { Total intercrop } \\
\text { yield } \\
\left(\mathrm{t} \mathrm{ha}^{-1}\right) \\
\end{array}$} \\
\hline maize & sesame & maize & sesame & \\
\hline $2012 \quad 2013$ & $2012 \quad 2013$ & 20122013 & $2012 \quad 2013$ & 2012 \\
\hline
\end{tabular}

\begin{tabular}{|c|c|c|c|c|c|c|c|c|c|c|}
\hline \multicolumn{11}{|l|}{$\begin{array}{l}\text { Intra-row } \\
\text { spacing } \\
\text { of sesame } \\
\text { Soles }\end{array}$} \\
\hline $\mathrm{M}+\mathrm{S}(10 \mathrm{~cm})$ & - & $\ldots$ & $\bar{\tau}$ & 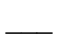 & 1.12 & 1.05 & 0.26 & 0.22 & 1.38 & 1.27 \\
\hline $\mathrm{M}+\mathrm{S}(15 \mathrm{~cm})$ & - & $\bar{\tau}$ & $\bar{\tau}$ & $\bar{\tau}$ & 1.20 & 1.17 & 0.29 & 0.23 & 1.49 & 1.40 \\
\hline $\mathrm{M}+\mathrm{S}(20 \mathrm{~cm})$ & {[} & - & {[} & {[} & 1.30 & 1.29 & 0.34 & 0.28 & 1.64 & 1.57 \\
\hline \multicolumn{11}{|l|}{$\begin{array}{l}\text { Frequency of } \\
\text { weeding }\end{array}$} \\
\hline Soles(2X) & 2.40 & 2.42 & 0.33 & 0.35 & 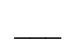 & 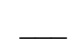 & $\underline{-}$ & $\ldots$ & - & $\underline{-}$ \\
\hline $\mathrm{M}+\mathrm{S}(1 \mathrm{X})$ & - & - & - & - & 2.12 & 2.15 & 0.27 & 0.30 & 2.39 & 2.45 \\
\hline $\mathrm{M}+\mathrm{S}(2 \mathrm{X})$ & - & - & - & 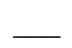 & 2.38 & 2.37 & 0.34 & 0.44 & 2.72 & 2.81 \\
\hline $\mathrm{M}+\mathrm{S}(\mathrm{NW})$ & 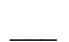 & 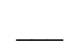 & $\underline{-}$ & $\underline{-}$ & 1.60 & 1.82 & 0.13 & 0.18 & 1.73 & 2.00 \\
\hline
\end{tabular}

Soles: sole sesame and sole maize respectively sown at their recommended intra-row spacing of $10 \mathrm{~cm}$ and $30 \mathrm{~cm}$., $\mathbf{M}+\mathbf{S}$ (10cm): maize with sesame sown at the intra-row spacing of $10 \mathrm{~cm} . \mathbf{M}+\mathbf{S}(\mathbf{1 5} \mathbf{~ c m})$ : maize with sesame sown at the intra-row spacing of $15 \mathrm{~cm}$., $\mathbf{M}+\mathbf{S}(\mathbf{2 0} \mathbf{~ c m})$ : maize with sesame sown at the intra-row spacing of $20 \mathrm{~cm} .$, Soles $(\mathbf{2 X})$ : sole sesame and sole maize sown at the recommended weeding regime (twice at 3 and 6 WAP)., $\mathbf{M}+\mathbf{S}(\mathbf{1} \mathbf{X})$ : maize-sesame intercrop sown on plots weeded once at 3 WAP.,M+S (2 X): maize-sesame intercrop sown on plots weeded twice at 3 and 6 WAP., $\mathbf{M}+\mathbf{S}$ (NW): maize-sesame intercrop sown on plots not weeded, WAP: weeks after planting.

Table 7. Evaluation of intercropping advantages of maize-sesame intercrop as influenced by the interaction of intra-row spacing of sesame x frequency of weeding at Makurdi, Nigeria, during 2012 and 2013 cropping seasons

\begin{tabular}{|c|c|c|c|c|c|c|c|c|c|c|c|c|c|c|c|}
\hline \multirow{2}{*}{$\begin{array}{l}\text { Intra-row } \\
\text { spacing } \\
\text { of sesame }\end{array}$} & \multirow{2}{*}{$\begin{array}{c}\text { Frequency } \\
\text { of } \\
\text { weeding }\end{array}$} & \multicolumn{2}{|c|}{$\mathrm{Lm}$} & \multicolumn{2}{|c|}{ Ls } & \multicolumn{2}{|c|}{ CR } & \multicolumn{2}{|c|}{ Aggressivity } & \multicolumn{2}{|c|}{ LEC } & \multicolumn{2}{|c|}{ LER } & \multicolumn{2}{|c|}{$\begin{array}{c}\% \\
\text { land saved }\end{array}$} \\
\hline & & 2012 & 2013 & 2012 & 2013 & 2012 & 2013 & 2012 & 2013 & 2012 & 2013 & 2012 & 2013 & 2012 & 2013 \\
\hline \multirow{3}{*}{$M+S(10 \mathrm{~cm})$} & $1 \mathrm{X}$ & 0.65 & 0.68 & 0.71 & 0.73 & 0.92 & 0.93 & -0.06 & -0.05 & 0.46 & 0.50 & 1.36 & 1.41 & 26.5 & 29.1 \\
\hline & $2 x$ & 0.68 & 0.69 & 0.86 & 0.07 & 0.79 & 0.64 & -0.18 & -0.38 & 0.58 & 0.74 & 1.54 & 1.76 & 35.1 & 43.2 \\
\hline & NW & 0.35 & 0.34 & 0.29 & 0.40 & 1.20 & 0.85 & 0.06 & -0.06 & 0.10 & 0.14 & 0.64 & 0.74 & -56.3 & -35.1 \\
\hline \multirow[b]{3}{*}{$\mathrm{M}+\mathrm{S}(15 \mathrm{~cm})$} & $1 \mathrm{X}$ & 0.67 & 0.69 & 0.83 & 0.90 & 0.81 & 0.77 & -0.16 & -0.12 & 0.56 & 0.62 & 1.50 & 1.59 & 33.3 & 37.1 \\
\hline & $2 x$ & 0.70 & 0.72 & 1.03 & 1.17 & 0.68 & 0.62 & -0.33 & -0.45 & 0.72 & 0.84 & 1.73 & 1.89 & 42.2 & 47.1 \\
\hline & NW & 0.38 & 0.40 & 0.34 & 0.50 & 1.12 & 0.80 & 0.04 & -0.10 & 0.13 & 0.20 & 0.72 & 0.90 & -38.9 & -11.1 \\
\hline \multirow{3}{*}{$M+S(20 \mathrm{~cm})$} & $1 \mathrm{X}$ & 0.68 & 0.70 & 0.91 & 1.17 & 0.75 & 0.60 & -0.23 & -0.47 & 0.62 & 0.82 & 1.59 & 1.87 & 37.1 & 46.5 \\
\hline & $2 X$ & 0.74 & 0.75 & 1.37 & 1.50 & 0.54 & 0.50 & -0.63 & -0.75 & 1.01 & 1.13 & 2.11 & 2.25 & 52.6 & 55.6 \\
\hline & NW & 0.44 & 0.45 & 0.51 & 0.67 & 0.86 & 0.67 & -0.07 & -0.22 & 0.22 & 0.30 & 0.95 & 1.12 & -5.3 & -10.7 \\
\hline
\end{tabular}

$\mathbf{M}+\mathbf{S}(\mathbf{1 0} \mathrm{cm}) \mathbf{1 X}$ : maize with sesame sown at the intra-row spacing of 10cm on plot weeded once at $3 \mathrm{WAP}$., $\mathbf{M}+\mathbf{S}(\mathbf{1 0} \mathbf{~ c m}) \mathbf{2 X}$ : maize with sesame sown at the intra-row spacing of $10 \mathrm{~cm}$ on plot weeded twice at 3 and 6 WAP., $\mathbf{M}+\mathbf{S}(\mathbf{1 0} \mathbf{~ c m}) \mathbf{N W}$ : maize with sesame sown at the intra-row spacing of $10 \mathrm{~cm}$ on plot not weeded.

$\mathbf{M}+\mathbf{S}(\mathbf{1 5} \mathbf{~ c m ) ~ 1 X}$ : maize with sesame sown at the intra-row spacing of $15 \mathrm{~cm}$ on plot weeded once at $3 \mathrm{WAP}$., $\mathbf{M}+\mathbf{S}(\mathbf{1 5} \mathbf{~ c m}) \mathbf{2 X}$ : maize with sesame sown at the intra-row spacing of $15 \mathrm{~cm}$ on plot weeded twice at 3 and 6 WAP., $\mathbf{M}+\mathbf{S}(\mathbf{1 5} \mathbf{~ c m}) \mathbf{N W}$ : maize with sesame sown at the intra-row spacing of $15 \mathrm{~cm}$ on plot not weeded.

$\mathbf{M}+\mathbf{S}(\mathbf{2 0} \mathbf{~ c m}) \mathbf{1 X}$ : maize with sesame sown at the intra-row spacing of $20 \mathrm{~cm}$ on plot weeded once at $3 \mathrm{WAP}$., $\mathbf{M}+\mathbf{S}(\mathbf{2 0} \mathbf{~ c m}) \mathbf{2 X}$ : maize with sesame sown at the intra-row spacing of $20 \mathrm{~cm}$ on plot weeded twice at 3 and 6 WAP., $\mathbf{M}+\mathbf{S}(\mathbf{2 0} \mathbf{~ c m}) \mathbf{N W}$ : maize with sesame sown at the intra-row spacing of $20 \mathrm{~cm}$ on plot not weeded.

WAP: weeks after planting, Lm: partial LER for maize., Ls: partial LER for sesame., CR: competitive ratio., LEC: land equivalent coefficient., LER: land equivalent ratio.

The average of both years indicated that the lowest competitive pressure and highest land equivalent coefficient values were recorded for intercropped maize with sesame sown at the intra-row spacing of $20 \mathrm{~cm}$, on plots weeded 2x at 3 and 6 WAP (Table 7). Adetiloye et al., (1983) reported that for a 
two crop mixture, the minimum expected productivity coefficient is $25 \%$. The highest level of aggressivity was recorded for maize in intercrop with sesame sown at the intra-row spacing of 10 $\mathrm{cm}$, on plots weeded $1 \mathrm{x}$ at $3 \mathrm{WAP}$. At this level of treatment, both crops dominated each other (Table 7). Highest land equivalent ratio (2.11 and 2.25 respectively, in years 2012 and 2013), and highest percentage (\%) land saved (52.6\% and 55.6\%, respectively, in years 2012 and 2013) were recorded for intercropped maize with sesame sown at the intra-row spacing of $20 \mathrm{~cm}$, on plots weeded $2 \mathrm{x}$ at 3 and 6 WAP (Table 7).

\section{CONCLUSION}

From the results obtained, it can be concluded that in a maize-sesame intercrop, increasing the intra-row spacing of sesame up to $20 \mathrm{~cm}$, on plots weeded 2x at 3 and $6 \mathrm{WAP}$ produced the highest intercropped yields of maize and sesame. At this level of treatment, both crops were found to be highly complementary and most suitable in mixture. This was associated with the highest total intercrop yields, lowest competitive ratio, highest land equivalent coefficient values, highest land equivalent ratio values and highest percentage land saved. It is however, recommended that further investigation of trial be done across different locations within the Guinea savannah agro-ecological zone of Nigeria.

\section{References}

[1] Adetiloye P.O., Ezedinma F.O.C., Okigbo, B.N., Ecology Modeling 19 (1983) 27-39.

[2] Alam S.M.N., Salim M., Islam N., Rahman M.N., International Journal of Sustainability in Crop Production 2(6) (2007) 31-33.

[3] Bedry K.A., University of Khartoum Journal of Agricultural Science 15 (2007) 220-231.

[4] Chiezey U.E., The Plant Scientist 2(1\&2) (2001) 121-133.

[5] Dudley T.S., James W., McCallum A. (2000). Texas Agricultural Experimental Station, College Station and Yankum, Prepared April 12, 2000, p. 125.

[6] El Naim A.M., Ahmed S.E., Australia Journal of Basic and Applied Sciences 4(9) (2010) 42504255.

[7] Enwezor W.O.E., Udo J., Ajotade K.A. (1989).Fertilizer procurement and distribution. Fertilizer use and management practice for crops in Nigeria. Savenda Publishers, Nsukka, Nigeria, pp. 2528.

[8] Ibeawuchi I.I., Obiefuna J.C., Ofoh M.C., Ihejirika G.O., Tom C.T., Onweremadu E.U., Opara C.C., Pakistan Journal of Biological Sciences 8 (2) (2005) 215-219.

[9] Ijoyah M.O., Iorlamen T., Fanen F.T., International Letters of Natural Sciences 18 (2014) 3646.

[10] Ijoyah M.O., Jimba J., Journal of Biodiversity and Environmental Science 2(2) (2012) 38-44.

[11] Iken J.E., Amusa N.A., African Journal of Biotechnology 3 (2004) 302-307.

[12] Iremiren G.O., Experimental Agriculture 24(02) (1988) 247-252.

[13] Jagtap S.S., Alabi R.T., Adeleye O., African Crop Science Journal 6(3) (1988) 259-272.

[14] Jakusko B.P., Usman B.D., Mustapha A.B., Journal of Agriculture and Veterinary Science 2(2) (2013) 36-39.

[15] Joshi K.R., Nepal Agricultural Research Journal 5 (2004) 69-70. 
[16] Kafiriti E.M., Deckers J. (2001).Sesame in crop production in tropical Africa. DGIC: Ministry of Foreign Affairs, External Trade and International Cooperation, Brussels, Belgium, Raw Mackers, R.H. (Ed.), p. 797-803.

[17] Kamara A.Y., Markir A., Ajala S.O., Experimental Agriculture 41 (2005) 199-212.

[18] Kling J.G., Edmeades G. (1997).Morphology and growth of maize. Research Guide No. 9 Training Programme, International Institute of Tropical Agriculture (IITA), Ibadan, Nigeria, Pp. 3-6.

[19] McGilchrist I.A., Biometrics Journal, 21 (1965) 975-985

[20] Moniruzzaman M., Uddin M.Z., Choudhury A.K., Bangladesh Journal of Agricultural Research 32(3) (2007) 393-402.

[21] Mubarak H.A. (2004). Studies on weed management in irrigated groundnut (Arachis hypogeae L.) in Sudan. Ph.D Thesis, Faculty of Agricultural Sciences, University of Gezira, Wad Medani, Sudan.

[22] Muneer A.P., Fida H.M., Muntaz A.K., Muhammad I.S., Journal of Applied Sciences 4(2) (2004) 201-205.

[23] Muoneke C.O., Asiegbu J.E., Journal of Agronomy Crop Science 179 (1997) 201-207.

[24] Ogindo H.O., Walker S., South Physical Chemistry Earth 30 (2005) 799-808.

[25] Olabode O.S., Adesina G.O., Ajibola A.T., Annals of Biological Research 4 (2010) 67-72.

[26] Olufajo O.O., Tropical Oil Seed Journal 1 (1992) 27-33.

[27] Poggio S.I., Agricultural Ecosystem and Environment 109 (2005) 48-58.

[28] Saha P.K., Aditya D.K., Sharfuddin A.F.M., Bangladesh Horticulture 17 (2005) 10-14.

[29] Silva P.S.L., Silva E.S., Mesquita S.S.X., Planta Daninha 22(1) (2004) 137-144.

[30] Silwana T.T., Lucas E.O., Journal of Agricultural Science 138 (2002) 193-200.

[31] Steel R.G.D., Torrie, J.H. (1980). Principles and procedures of statistics. A Biometrical Approach, $2^{\text {nd }}$ edition, McGraw Hill, New York, 633pp.

[32] Suleiman A.A. (2005). Genetic and inter-relationships among agronomic character in roselle (Hibiscus sabdariffa L.) M.Sc Thesis, Faculty of Natural Resources and Environmental Studies, University of Kordofan, Sudan.

[33] Uzozie P.R., Journal of Agricultural Science 12 (2001) 18-21.

[34] Willey R.W., Expl. Agric. 21 (1985) 119-133.

[35] Willey R.W., Rao M.R., Expl. Agric. 16 (1980) 117 - 125. 